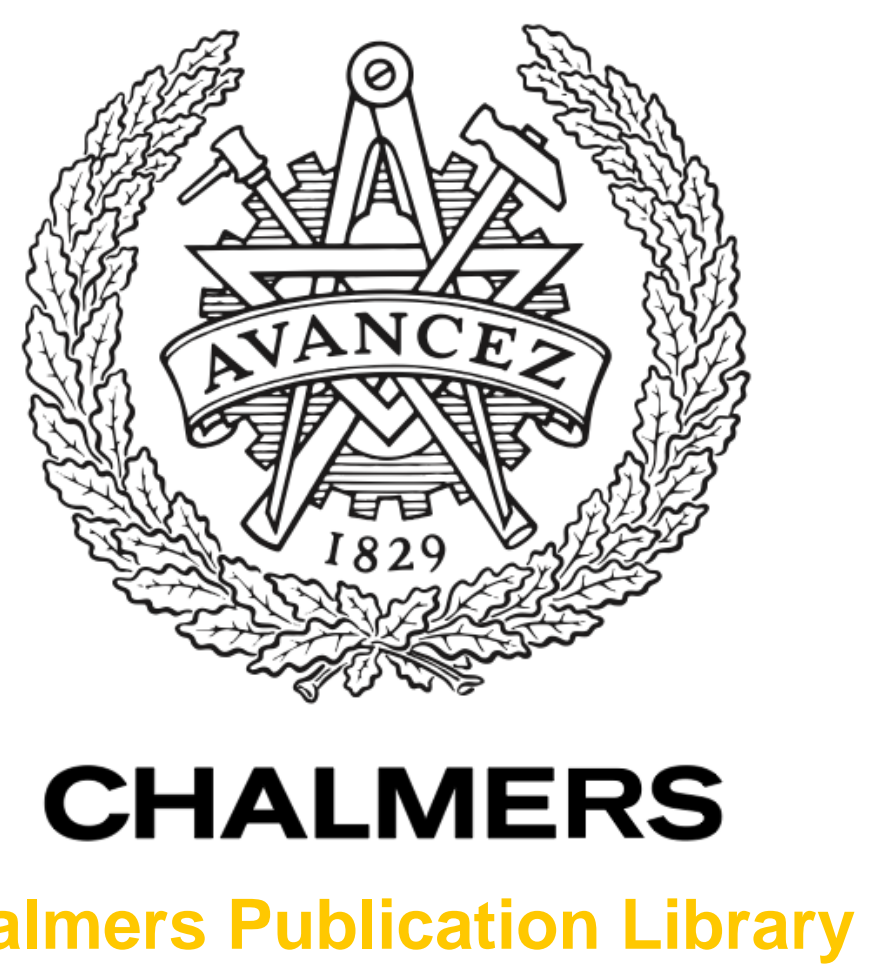

\title{
Incorporating the soil function concept into sustainability appraisal of remediation alternatives
}

This document has been downloaded from Chalmers Publication Library (CPL). It is the author's version of a work that was accepted for publication in:

Journal of Environmental Management (ISSN: 0301-4797)

Citation for the published paper:

Volchko, Y. ; Norrman, J. ; Bergknut, M. et al. (2013) "Incorporating the soil function concept into sustainability appraisal of remediation alternatives". Journal of Environmental Management, vol. 129 pp. 367-376.

http://dx.doi.org/10.1016/j.jenvman.2013.07.025

Downloaded from: http://publications.lib.chalmers.se/publication/192395

Notice: Changes introduced as a result of publishing processes such as copy-editing and formatting may not be reflected in this document. For a definitive version of this work, please refer to the published source. Please note that access to the published version might require a subscription. 
- A terminology related to the soil function concept is suggested distinguishing functions and services provided by soil resources.

- A conceptualization of the linkages between soil functions and ecosystem services connected to the three domains of sustainability is presented.

- Using a Multi-Criteria Decision Analysis and the above mentioned conceptualization, the paper provides a general approach for evaluating soil functions in remediation projects.

- Potential negative and positive effects of remediation technologies on the functionality of the treated soil are examined by reviewing relevant literature sources. 
2
Yevheniya Volchko $^{\mathrm{a},{ }^{*}}$, Jenny Norrman ${ }^{\mathrm{a}}$, Magnus Bergknut ${ }^{\mathrm{b}, \mathrm{c}}$, Lars Rosén $^{\mathrm{a}}$, Tore Söderqvist ${ }^{\mathrm{d}}$

a Department of Civil and Environmental Engineering, Chalmers University of Technology, SE-412 96 Göteborg, Sweden,

${ }^{\mathrm{b}}$ Department of Chemistry, Umeå University of Technology, SE-901 87 Umeå, Sweden,

${ }^{c}$ Envix, SE-906 20, Umeå, Sweden

${ }^{d}$ Enveco Environmental Economics Consultancy Ltd., Måsholmstorget 3, SE-127 48

Skärholmen, Sweden

*Corresponding author, tel.:+46 031 7722116, fax: +46 031772 2107, e-mail address: volchko@chalmers.se 
1 Abstract

Soil functions are critical for ecosystem survival and thus for an ecosystem's provision of services to humans. This is recognized in the proposed EU Soil Framework Directive from 2006, which lists seven important soil functions and services to be considered in a soil management practice. Emerging regulatory requirements demand a holistic view on soil evaluation in remediation projects. This paper presents a multi-scale, structured and transparent approach for incorporating the soil function concept into sustainability appraisal of remediation alternatives using a set of ecological, socio-cultural and economic criteria. The basis for the presented approach is a conceptualization of the linkages between soil functions and ecosystem services connected to with the sustainability paradigm. The approach suggests using (1) soil quality indicators (i.e. physical, chemical and biological soil properties) for exploring the performance of soil functions at the site level, and (2) soil service indicators (i.e. value-related measurements) for evaluating the performance of services resulting from soil functions across all levels of the spatial scale. The suggested approach is demonstrated by application ina Multi-Criteria Decision Analysis (MCDA) framework for sustainability appraisals of remediation alternatives. Further, the possibilities of using soil quality indicators for soil function evaluation are explored by reviewing existing literature on potential negative and positive effects of remediation technologies on the functionality of the treated soil. The suggested approach for including the soil function concept in remediation projects is believed to provide a basis for better informed decisions that will facilitate efficient management of contaminated land and to meet emerging regulatory requirements on soil protection.

Keywords: soil functions, ecosystem services, contaminated sites, remediation, sustainability assessment, multi-criteria decision analysis

\section{Introduction}

Soil contamination continues to be a widespread threat to the soils throughout the world, and has resulted in a wide array of remediation techniques and management options (FRTR, 2002). The land management practice reveals that remediation aimed at revitalization of contaminated sites is at the core of achieving sustainable development in the built environment (Bardos, 2003; Bardos et al., 2000; Schädler et al., 2011). Still, the remedial action in itself needs to be sustainable in a wide context, taking into account the ecological, the economic as well as the socio-cultural domains of sustainability (Bardos et al., 2011; Rosén et al., 2009; SuRF-UK, 2011, 2010). The current best practice for managing contaminated sites, i.e. risk-based land management, is aimed at achieving "fitness for use" appropriate to the location on the basis of risk reduction, taking into account environmental effects and socio-economic consequences (Bardos et al., 2011; Vegter et al., 2003). It is, however, evident that emerging regulatory requirements on soil protection advocate a holistic view on future management of contaminated sites (Bone et al., 2010a, 2010b; Rodrigues et al., 2009). Such a view holds that there is a crucial need for comprehensive assessment of the soil in remediation projects, accounting for soil functions and services.

The soil functions and services as included in the proposed EU Soil Framework Directive are (i) biomass production, including agriculture and forestry; (ii) storing, filtering and 
transforming nutrients, substances and water; (iii) biodiversity pool, such as habitats, species and genes; (iv) physical and cultural environment for humans and human activities; (v) source of raw materials; (vi) acting as carbon pool; (vii) archive of geological and archeological heritage (COM, 2006). Since soil functions are critical for ecosystem survival and thus for ecosystem's provision of services to humans, it is critical to evaluate soil performance when assessing sustainability in remediation projects.

Evaluation of the above mentioned soil functions and services includes handling of various, sometimes conflicting, criteria accounting for multiple soil functions and uses, as well as accounting for multiple stakeholder views (Lehmann and Stahr, 2010). A tool for handling such a complex task is Multi Criteria Decision Analysis (MCDA). Critical literature reviews of approaches to and methodologies for MCDA in natural resource management are provided by Linkov et al. (2006) and Mendoza and Martins (2006). Usually, the main objective of an MCDA is to assess to what degree a number of decision alternatives fulfil a set of performance criteria (Mendoza and Martins, 2006). The criteria are typically evaluated for each alternative so that all studied alternatives can be ranked. Thus, selecting criteria and weighting their importance are fundamental parts of the MCDA. Criteria of the ecological, socio-cultural and economic domains of sustainability form a common structure for appraisal in soil remediation projects (e.g. Bardos et al., 2011; Brinkhoff, 2011; Postle et al., 1999; Rosén et al., 2009; SuRF-UK, 2010) and in sediment remediation projects (e.g. Linkov et al., 2004; Sparrevik et al., 2011), usually assuming a risk-based approach to land and sediment management. Further, a recent study by SuRF-UK (2011) suggests a holistic approach to management of contaminated sites accounting for ecosystem functions, goods and services provided by soil resources. There are, however, no studies on sustainability appraisal of remediation alternatives that explicitly explore the linkages between soil functions, ecosystem services, and the sustainability domains.

\section{Aim and scope}

The aim of this paper is to provide a structured approach for incorporating the soil function concept into sustainability appraisal of remediation alternatives and to demonstrate how this approach to soil function evaluation can be used within an MCDA framework. The first step in achieving this objective (aim) is to provide the reader with the terminology used in this paper and suggest a hierarchy between soil functions, soil processes, soil services and ecosystem services (Section 3). Thereafter, the paper presents a conceptualized hierarchy for connecting soil functions and ecosystem/soil services with the ecological, economic, and socio-cultural domains of sustainability (Section 4). Section 5 presents a suggested approach for evaluation of soil function performance within the scope of sustainability appraisal of remediation alternatives. Section 6 demonstrates application of the approach within an MCDA framework. Section 7 details specific constraints of soil function evaluation with respect to potential effects on soil quality caused by remediation. Finally, the last two sections provide the reader with a discussion of the suggested approach as well as some brief conclusions. 
The novelty of the presented study is the conceptualization of the linkages between soil functions and ecosystem services connected to the three common sustainability domains (Section 4). This is not generally discussed in existing literature and allows for scaling of soil performance evaluation in an MCDA framework from site-specific observations to assessment of global socio-economic effects. This study presents an approach for how to operationalize the inclusion of the soil function concept in remediation projects in order to provide a basis for better informed decisions, to facilitate efficient management of contaminated land, and to meet emerging regulatory requirements on soil protection.

\section{Terminology}

This section defines the terms used in this paper and suggests a hierarchy between soil functions and services, recognizing that some terms can be used differently in another field or discipline. The suggested terminology is based on literature studies, mainly considering works in environmental economics (e.g. Costanza et al., 1997; de Groot et al., 2002; de Groot, 2006; Ekins et al., 2003; Fisher et al., 2009; Hein et al., 2006; Gibson et al., 2000), soil science (e.g. Lehmann et al., 2008; Lehman and Stahr, 2010, Schindelbeck et al., 2008), and other environmental fields (e.g. Blum, 2005; Bone et al., 2010a; Cash et al., 2006; Johnson et al., 1997; Lamarque et al., 2011). Confusion about the specified terminology usually stems from (i) interchangeable use of ecosystem services with such terms as ecological, landscape, and environmental services (see e.g. the exhaustive literature study by Lamarque et al., 2011); (ii) various definitions of soil quality (see e.g. the compiled definitions in Bone et al., 2010a), as well as various interpretation of the term soil quality in relation to environmental change and soil degradation (see e.g. a review of terminology by Johnson et al., 1997); (iii) interchangeable use of the term scale with such terms as resolution, dimension, and level (see e.g. reviews by Gibson et al., 2000 and Cash et al., 2006); and finally (iv) unclear differences between soil functions and the services resulting from these functions. Sometimes the soil function concept is used to describe the internal functioning of a soil system (e.g. Lehmann et al. 2008; Lehmann and Stahr, 2010; Shchindelbeck, 2008) and sometimes it relates to the benefits humans directly (or indirectly) gain from the soil systems (e.g. de Groot, 2006). The proposed EU Soil Framework Directive (COM, 2006) combines both these aspects of the soil function concept.

Soil function is here defined as a capacity of soil to fulfil the requirements assigned to it by nature, i.e. what the soil does in its natural state. Based on the study of de Groot et al. (2002), each soil function, being a subset of an ecosystem function, is recognized as the result of the soil processes arising out of the complex interactions between living (biological) and nonliving (physical and chemical) soil components through the universal driving forces of matter and energy.

Soil processes are equivalent to the definition of ecosystem processes by Groot et al. (2002). For example, purification of water is a soil process that may provide several soil functions such as filtration and degradation of contaminants. 
3

Soil quality is, in the context of soil remediation, defined as suitability in relation to the end use of the soil (Johnson et al., 1997).

Soil quality indicators are defined as the measurable properties of soil used to evaluate the degree to which the soil quality matches the soil functions determined by the intended end use of the soil, e.g. land use. These soil quality indicators for soil function evaluation may encompass physical, chemical and biological parameters (Schindelbeck et al., 2008).

A soil service is a soil function which has been directly or indirectly utilized by an individual or society to yield human well-being. As such, a soil function immediately turns into a soil service once it has been delivered to and utilized by humans.

A soil service indicator is defined as a value-related measurement that indicates to which degree a management action contributes to human well-being by preserving, restoring and/or enhancing a soil service. These value-related measurements can be expressed in: (1) community-based values which reflect attitudes, preferences, and intentions associated with a soil service; (2) economic values revealed by market data (if any) about a soil service, or the willingness to pay (WTP) for the service provided by the end use of the soil (SAB, 2009).

Soil use is in this study defined as a direct or indirect utilization of soil resources by humans. For example, soil resources can be utilized as a construction material, a construction ground, a basis for human activities, an archeological archive, or a source of inspiration and aesthetic experiences.

Land use is defined as arrangements, activities and inputs humankind undertake in order to produce, change or maintain the observed biophysical cover on earth's surface, including water, vegetation, bare soil, bare rock and artificial structures (FAO, 1997).

Ecosystem services are defined as ecosystem functions utilized by humanity, either directly or indirectly, to produce human well-being (Fisher et al., 2009). As such, ecosystem services include the services provided collaboratively by soil, air, water, and biota. It could hence be argued that most soil services are in fact ecosystem services as soil seldom is the sole contributor to a specific service.

The terms soil function and soil service are used in this study to specify the ecosystem function and the ecosystem service resulting from ecosystem processes where the soil is the dominant component or driving force.

The distinction between soil goods and soil services is ignored here, in analogy with Costanza et al. (1997) for ecosystem goods and ecosystem services.

Scale is defined as analytical dimensions designed to observe and study any phenomenon in space and time using levels as the units of analysis, which are located at different positions on a scale (Gibson et al., 2000; Cash et al., 2006). For example, an organism, an ecosystem, a 
landscape, a biome, a biosphere can be considered as different observation levels on the ecological scale.

\section{Conceptualized hierarchy between soil functions and services aligned with the sustainability paradigm}

As the aim of a sustainability appraisal of remediation alternatives is to evaluate whether a remediation alternative contributes to sustainable development or not, it is important to link the hierarchy between functions, processes and services provided by an ecosystem, including a soil system (see Section 3), with the three domains of sustainability. We suggest an hourglass model to clearly illustrate the above mentioned linkages and the hierarchy (Fig. 1).

In the ecological domain the ecosystem processes are based on the ecosystem structure and interactions between its biotic and abiotic components (de Groot et al., 2002). These processes result in ecosystem functions. Ecosystem functions turn into ecosystem services once they are used by humans and thus passing through the socio-cultural domain (Fisher et al., 2009). When an ecosystem service has an economic value (Turner et al., 2000), this service is transferred to the economic domain (Fig. 1).

The bottleneck in the hourglass model is utilization (Fig.1). Like sand grains are flowing faster through a wider neck of an hourglass so are natural resources quickly depleting through overuse, which is changing the potential of supplying ecosystem services. Safeguarding this supply requires (1) ecosystems capable of properly regulating the essential ecological processes through structures, functions, and biogeochemical cycles (Rönnbäck et al., 2007); and (2) a sustainable utilization of the natural resources. The limits of such utilization (i.e. the neck width of the sustainability hourglass in the suggested allegory) are usually defined on the political level by developing and adapting a variety of regulatory requirements and environmental laws, e.g. the proposed EU Soil Framework Directive (COM, 2006) for sustainable use of soil resources.

When managing or governing natural resources, it is critical to keep the balance between the ecological, socio-cultural and economic domains by supporting ecosystems' functioning in return for enjoying, consuming and utilizing ecosystem services. By flipping over the hourglass of sustainability and placing the economic domain on top (Fig. 1), ecosystems' functioning is sustained by investments aimed at compensating the degradation that human utilization of natural resources might imply. However, some ecosystems' components and processes are unique and irreversible over relevant time horizons and thus cannot be compensated (van den Bergh, 2010). This implies that although a total change in all three sustainability domains might be positive as a result of a management action, a compensation of a negative change in a certain domain by a positive change in another one would therefore lead towards weak sustainability (Ekins et al., 2003; van den Bergh, 2010). A strong sustainability perspective, in contrast, implies that a management action must generate only positive changes in all three domains of sustainability without allowing for compensation.

\section{A suggested approach to soil function evaluation within an MCDA framework}


1 A sustainability appraisal within a generic MCDA framework in remediation projects

2 typically includes six basic steps (see e.g. Sparrevik et al., 2011): (1) formulation of the

3 objectives and identification of an MCDA method, (2) generation of remediation alternatives,

4 (3) criteria and metrics development, (4) evaluation of the generated alternatives against

5 criteria in the ecological, the socio-cultural, the economic domains of sustainability,

6 (5) criteria weighting (i.e. identifying their relative importance), and (6) information

7 synthesis, comparison of remediation alternatives based on their overall performance on the

8 criteria, and sensitivity analysis of the obtained results (Fig. 2). The incorporation of the soil

9 function concept as included in the proposed Soil Framework Directive (COM, 2006) is

10 achieved by allocating the soil functions towards the ecological domain and the soil services

11 towards the socio-cultural and the economic domains of an MCDA. The effects of identified

12 remediation alternatives on the soil performance can be measured using soil quality and soil

13 service indicators (Fig. 2).

Soil quality indicators can be used to evaluate to what degree a quality of the remediated soil matches soil functions relevant to intended land uses within the boundaries of the remediation site. For example, the performance of the soil functions ( $i$ ) storing, filtering and transforming nutrients, substances and water and (ii) biodiversity pool, such as habitats, species and genes as listed in the proposed Soil Framework Directive (COM, 2006) can be evaluated using the correlations between the soil quality indicators and soil functions suggested by Lehmann and Stahr (2010) or Schindelbeck et al. (2008). However, there are some challenges associated with usage of these soil evaluation methods within an MCDA of remediation alternatives (see Section 7).

Soil service indicators can be used to evaluate the degree a remedial action contributes to human well-being by preserving, restoring and/or enhancing soil services provided by intended land use. For example, the soil service indicators can be explored using the framework for integrated assessment of ecosystem functions, goods and services (de Groot et al., 2002; MA, 2005). In this study these soil service indicators are suggested to address: (1) relevant criteria of the socio-cultural domain by examining community-based values, i.e. the attitudes, preferences, and intentions of an individual or group of individuals towards the effects associated with the remediation alternative; and/or (2) the criteria of the economic domain by assessing the economic values associated with the change in the soil service caused by remediation (Fig. 2). The soil-related criteria in the economic domain can be addressed in terms of the effects caused by remediation on market and non-market priced soil services. The soil's abilities to serve as (i) a source of raw materials and (ii) as a basis for biomass production including agriculture and forestry are valued in markets and are thus market priced soil services. The same is true for a soil's ability to serve as a basis for housing and construction, where the development value of land is observable in a market place. This ability of the soil to some extent corresponds to the soil service physical and cultural environment for humans and human activities, as included in the proposed Soil Framework Directive (COM, 2006). However, such soil services as (1) acting as carbon pool and (2) archive of geological and archeological heritage can be defined as non-market priced soil services, because they are freely available for humans as an element of nature. 


\section{Demonstration example}

3 This section presents a demonstration of the suggested approach to soil function evaluation using an MCDA prototype for sustainability appraisal of remediation alternatives developed by Rosén et al. (2009). The MCDA prototype uses the common three pillar sustainability model: ecology, economy, and socio-culture. In the economic domain, costs and benefits are measured quantitatively in monetary terms using Cost-Benefit Analysis (CBA) (Rosèn et al., 2008). The CBA addresses social profitability which is the only criterion in the economic domain. In the ecological and socio-cultural domains, qualitative scores are assigned to a number of key criteria (Table 1). Each criterion is scored between -2 representing "very negative effect" and +2 representing "very positive effect" relative to a reference alternative. A score of 0 represents "no effect". Importantly, the effects of remediation alternatives are measured relative to the reference alternative, e.g. when no remedial action is taken. The MCDA prototype is currently being further developed and parts of this work can be found in Norrman et al. (2012).

The MCDA prototype is based on a linear additive model (to rank the remediation alternatives) in combination with a non-compensatory method (to exclude those alternatives which are regarded as not leading towards sustainability). The most sustainable alternative is the one which generates the highest sustainability index in the interval $[-1 ;+1]$. If the remediation alternative generates a positive sustainability index, it is regarded as leading towards weak or strong sustainability. It is considered as leading towards strong sustainability if it performs positively on all key criteria, i.e. without allowing for compensation among key criteria. The perspectives of strong and weak sustainability have also been adapted in an MCDA model for sustainability assessment in regional planning projects (Boggia and Cortina, 2010).

The soil service indicators can be used to address (a) the cultural environment, the recreation and the land use on site criteria in the socio-cultural domain of the MCDA prototype (Table 1 ), as well as (b) the social profitability criterion in the economic domain in terms of the effects caused by remediation on market and non-market priced soil services. For example, WTP studies can be used to monetize the benefits associated with increased recreational opportunities on the remediated site as suggested to be included in the CBA by Rosèn et al. (2008).

\section{Challenges: using soil quality indicators within an MCDA framework}

Since methods for soil function evaluation is typically based on interpretation of the effects on a minimum data set (MDS) of soil quality indicators (e.g. Lehmann et al., 2008), the indicators can provide an important input for the ecological domain of the MCDA framework. However, there is no standardized MDS (Bone et al., 2006a). Further, there is a lack of knowledge on the relationship between the soil quality indicators and the soil functions (Lehmann and Stahr, 2010). Still, there are some known correlations that are used for soil function evaluation. For example, the stagnic luvisol soil with $p H$ of 7.5, humus content of 1$3 \%$, coarse material of $0-1 \%$, bulk density of $1.3-1.6 \mathrm{~g} / \mathrm{cm}^{3}$, soil depth of $1 \mathrm{~m}$ corresponds to a 
very poor performance of the soil function biodiversity pool (Lehmann et al., 2008). To apply the soil function evaluation method within an MCDA, there is a need not only to know how to interpret the effects on a set of soil quality indicators but also to know how available in- and ex-situ remediation technologies would impact these indicators. The state of the art and available knowledge concerning the latter was in this study assessed by performing a review of available literature (Tables 2 and 3). A brief description of identified studies aimed at evaluation of the changes in soil functions after treatment, including the references and examined remediation technologies, is presented in Table 2. Further, the impacts of these technologies on the examined soil quality indicators are compiled in Table 3.

From table 3 it is clear that a successful MDS of soil quality indicators should include physical, chemical and biological indicators. For such as set to be useful in practice, focus should be on indicators that are easy to measure, e.g. water holding capacity, organic matter content, $\mathrm{pH}$, available nitrogen, available phosphorus, and microbial activity. Further research is needed to propose a general MDS to be used in an MCDA, to study the interplay between soil quality indicators, the relationship between indicators and the functions, and the impact by remediation.

\section{Discussion}

This study presents a structured approach for incorporating the soil function concept into an MCDA framework for sustainability appraisal of remediation alternatives. By exploring the linkages between ecosystem functions and services provided by soil resources as well as the sustainability domains, the presented approach suggests allocating soil functions to the ecological domain, and soil services to the socio-cultural and the economic domains of the appraisal. In contrast, in the recent study by SuRF-UK (2011) ecosystem functions, goods and services provided by the soil are suggested to be evaluated in the ecological domain. However, as evident from the definitions of ecosystem goods and services usually used in environmental economics (see Sections 3 and 4), the goods and services resulting from soil functions might be more relevant to socio-economic effects of remediation. Admittedly, these socio-economic effects have a multi-scale characteristic, because ecosystem services are spread across all levels of the spatial scale (Hein et al., 2006). By using soil service indicators, as suggested in this study, the socio-economic effects resulting from the performance of remediated soil could be evaluated from the site to the global levels.

The approach allows scaling of soil performance assessment from site-specific observations for the appraisal of global socio-economic effects. Scaling is suggested to be achieved by using the soil quality indicators in the ecological domain of the MCDA and soil service indicators in the socio-cultural and the economic domains. At what level of the spatial scale the performance of the soil is evaluated in the ecological domain will depend on the size of the remediation site. Even though the area of the contaminated site in question is relatively small (less than one square kilometre), the changes in the physical, chemical and biological properties of the soil on the local level can impact the whole ecosystem on the regional level (Schindelbeck et al., 2008). Thus the size of the site should be taken into consideration with respect to the potential ecological effects of a remedial action on the ecosystem at the regional 
level. For example, an altered capacity to drain and store water as a result of soil treatment within the boundaries of the site on the local level can affect the groundwater recharge potential on the regional level.

Sometimes the same soil service can be evaluated twice: when addressing the socio-cultural and the economic domains of sustainability. This introduces a problem of double-counting only in the special case when economic values are considered to reflect all other types of values. Assigning economic values hinges on the individualistic view that well-being is determined by the degree of preference satisfaction, which typically is monetized through willingness to pay (WTP) (Hausman and McPherson, 1996). For example, if the provision of drinking water is a soil service restored by the remedial action, the WTP for drinking water can be a money-related expression of the environmental change associated with remediation of the contaminated soil. WTP is the economic value people place on the service based on what they think is appropriate for them as individuals rather than what is beneficial for society as a whole since the choice is directly connected to, and constrained by, personal income (SAB, 2009). However, the same individuals taking a community well-being perspective can place another kind of value, e.g. ethical value, on the same service, denoting the degree of its importance for humanity, which is not necessarily reflected in their WTP. Thus, there might be a fundamental difference between their roles as consumers and citizens (Sagoff, 2007).

In general, soil remediation is performed to reduce risks of negative impact on health and the environment posed by contaminants in the soil. The level of reduction is usually linked to the intended land use, i.e. the allowable concentration levels of contaminants in the soil after treatment with respect to the end use of the site. For example, chemical soil quality requirements for residential areas are stricter than for industrial areas, parking spaces or roads (van Hees et al., 2008). The end use of the site will also have a direct impact on the targeted soil functions (Lehmann and Stahr, 2010). There is, however, a need for a project-specific soil assessment for evaluating the effects of remediation alternatives on soil functions, as there are still few studies on impacts on soil functions by remediation technologies (Table 2). The research results on the effects of remediation on soil quality in terms of its functionality (Table 3) are difficult to generalize for application in an MCDA, since these results are relevant only for some technologies, some soil types, and some soil functions. The rather limited results from the scarce literature sources can still be used within the MCDA. For example, if the identified remediation alternatives within an MCDA are (1) immobilization of contaminants with biosolids combined with lime, and (2) phytoextraction by Lolium perenne with organic amendments, then according to the results in Table 3, the effects of these alternatives on the soil function biodiversity pool would be very positive.

In turn, the end use of the site will also impact the targeted soil services resulting from the functions. This implies that a site designed for residential redevelopment will provide different soil functions and services compared to a site for recreation or biomass production. Accordingly, different end uses of the remediated site will result in different sets of soil functions and services. The land use scenarios should be identified at an early stage of the sustainability assessment. Once land uses and a corresponding set of the soil functions and 
services are identified, relevant soil quality indicators and soil service indicators can be used to evaluate the effects associated with available remediation alternatives.

Evaluation of the soil performances should be included into sustainability appraisal of remediation alternatives in order to stringently assess remediation alternatives as to whether they lead to sustainable development and thus safeguard the soil functions and services. Considering the importance of soil functions and services for ecosystems and humans, additional costs accrued by the inclusion of the soil function concept in an MCDA of remediation alternatives might be motivated from a social perspective and be compensated by implementation of more cost-effective and innovative remediation alternatives.

\section{Conclusions}

The following main conclusions were drawn from this study:

- Soil performance evaluation is achieved on different spatial scales by using (1) soil quality indicators (i.e. physical, chemical and biological soil properties) that reflect effects on soil functions at the site level, and (2) soil service indicators (i.e. value-related measurements) that reflect effects on services resulting from soil functions across all levels of the spatial scale.

- The conceptualized hierarchy between soil functions and services, as well as the suggested approach for soil performance evaluation can be generalized to application in various land management projects using MCDA approaches to sustainability assessment of decision alternatives based on the three pillar model.

- Identification of suitable soil quality indicators and soil service indicators for evaluating the performance of soil functions in remediation projects is recognized as a priority topic for future research. As evident from this study, there is a need for further investigation aimed at establishing the potential negative and positive impacts of various remediation technologies on the soil quality in the context of the soil functionality.

\section{Acknowledgements}

The authors acknowledge the SNOWMAN ERA-Net and the Swedish Research Council Formas for financial support. The principal author thanks Karin Holmgren for computer graphics of the sustainability hourglass and Professor Christine Räisänen for advice, both at Chalmers University of Technology.

\section{References}

Bardos, P., 2003. A review of the Contaminated Land Rehabilitation Network for Environmental Technologies in Europe (CLARINET). Part 2: Working Group findings. Land Contamination \& Reclamation 11 (1), 15-30.

Bardos, P., Bone, B., Boyle, R., Ellis, D., Evans, F., Harries, N.D., Smith, J.W.N., 2011. Applying Sustainable Development Principles to Contaminated Land Management using the SuRF-UK Framework. Remediation 21(2), 1-138.

Bardos, P.R., Nathanail, C.P., Weenk, A., 2000. Assessing the Wider Value of Remediating Land Contamination: A Review. R\&D report P238. UK Environmental Agency, Bristol. http://publications.environment-agency.gov.uk/ (assessed May 01.05.11). 
Blum, W.E.H., 2005. Functions of soil for society and the environment. Reviews in Environmental Science and Bio/Technology 4, 75-79.

Boggia, A., Cortina, C., 2010. Measuring sustainable development using a multi-criteria model: A case study. Journal of Environmental Management 91, 2301-2306.

Bone, J., Head, M., Barraclough, D., Archer, M., Scheib, C., Flight, D., Voulvoulis, N., 2010a. Soil quality assessment under emerging regulatory requirements. Environment International 36, 609-622.

Bone, J., Head, M., Jones, D.T., Barraclough, D., Archer, M., Scheib, C., Eggleton, P., Voulvoulis, N., 2010 b. From Chemical Risk Assessment to Environmental Quality Management: The Challenge for Soil Protection. Environmental science and technology 45(1), 104-110.

Brinkhoff, P., 2011. Multi-Criteria Analysis for Assessing Sustainability of Remediation Actions: Applications in Contaminated Land Development. A Literature Review. Chalmers Reproservice, Gothenburg, Sweden. 102 p.

Cash, D.W., Adger, W., Berkes, F., Garden, P., Lebel, L., Olsson, P., Pritchard, L., Young, O., 2006. Scale and cross-scale dynamics: governance and information in a multilevel world. Ecology and Society 11(2), 8 p. http://www.ecologyandsociety.org/vol11/iss2/art8/ (accessed 23.05.11).

COM, 2006. Proposal for a Directive of the European Parliament and of the Council establishing a framework for the protection of soil and amending Directive 2004/35/EC. Brussels, Belgium. http://ec.europa.eu/environment/soil/pdf/com_2006_0232_en.pdf (accessed 03.06.10).

Costanza, R., d'Arge, R., de Groot, R., Farber, S., Grasso, M., Hannon, B., Limburg, K., Naeem, S., O'Neill, R. V., Paruelo, J., Raskin, R. G., Sutton, P., van den Belt, M., 1997. The Value of the World's Ecosystem Services and Natural Capital. Nature 387, 253-260. Dawson, J.J.C., Godsiffea, E.J., Thompson, I.P., Ralebitso-Senior, T.K., Killhama, K.S., Paton, G.I., 2007. Application of biological indicators to assess recovery of hydrocarbon impacted soils. Soil Biology \& Biochemistry 39, 164-177.

de Groot, R., 2006. Function-analysis and valuation as a tool to assess land use conflicts in planning for sustainable, multifunctional landscapes. Landscape and Urban Planning 75, 175-186.

de Groot, R.S., Wilson, M.A., Boumans, R.M.J., 2002. A typology for the classification, description and valuation of ecosystem functions, goods and services. Ecological Economics 41, 393-408.

Ekins, P., Simon, S., Deutsch, L., Folke, C., de Groot, R., 2003. A framework for the practical application of the concepts of critical natural capital and strong sustainability. Ecological Economics 44, 165-185.

Epelde, L., Hernóndez-Allica, J., Becerril, J.M., Blanco, F., Garbisu, C., 2008 a. Effects of chelates on plants and soil microbial community: Comparison of EDTA and EDDS for lead phytoextraction. Science of The Total Environment 401(1-3), 21-28.

Epelde, L., Becerril, J. M., Hernóndez-Allica, J., Barrutia, O., Garbisu, C., 2008 b. Functional diversity as indicator of the recovery of soil health derived from Thlaspi caerulescens growth and metal phytoextraction. Applied Soil Ecology 39(3), 299-310.

Epelde, L., Becerril, J.M., Mijangos, I., Garbisu, C., 2009 a. Evaluation of the efficiency of a phytostabilization process with biological indicators of soil health. Journal of Environmental Quality 38(5), 2041-2049. 
Epelde, L., Becerril, J.M., Kowalchuk, G.A., Deng, Y., Zhiu, J., Garbisu, C., 2010. Impact of Metal Pollution and Thlaspi caerulescens Growth on Soil Microbial Communities. Applied and Environmental Microbiology 76 (23), 7843-7853.

FAO, 1997. Africover land cover classification. Food and Agriculture Organization of the United Nations, Rome.

Fisher, B., Turner, K.R., Morling, P., 2009. Defining and classifying ecosystem services for decision making. Ecological economics 68, $643-653$.

FRTR, 2002. Remediation Technologies Screening Matrix and Reference Guide, fourth ed., USA. http://www.frtr.gov/matrix 2/section1/toc.html (assessed 20.10.10).

Johnson, D.L., Ambrose, S.H., Bassett, T.J., Bowen. M.L., Crummey, D.E., Isaacson, J.S., Johnson, D.N., Lamb, P., Saul, M., Winter-Nelson, A.E., 1997. Meanings of environmental terms. Journal of Environmental Quality 26, 581-589.

Gibson, C.C., Ostrom, E., Ahn, T.K., 2000. The concept of scale and the human dimensions of global change: a survey. Ecological Economics 32, 217-239.

Hausman, D.M., McPherson, M.S., 1996. Economic Analysis and Moral Philosophy. Cambridge University Press, Cambridge, UK.

Hein, L., van Koppen, K., de Groot, R.S., van Ierland, E.C., 2006. Spatial scales, stakeholders and the valuation of ecosystem services. Ecological Economics 57, 209- 228.

Lamarque, P.,Quètier, F., Lavorel, S., 2011. The diversity of the ecosystem services concept and its implications for their assessment and management. C. R. Biologies, 334, 441-449.

Lehmann, A., David, S., Stahr, K., 2008. TUSEC - A manual for the evaluation of Natural Soils and AnthropogenicUrban Soils. Bilingual edition. Hohenheimer Bodenkundliche Hefte, Stuttgart. $224 \mathrm{p}$.

Lehmann, A., Stahr, K., 2010. The potential of soil functions and planner-oriented soil evaluation to achieve sustainable land use. Journal of Soils Sediments 10, 1092-1102.

Lear, G., Harbottle, M.J., Sills, G., Knowles, C.J., Semple, K.T., Thompson, I.P., 2007. Impact of electrokinetic remediation on microbial communities within PCP contaminated soil. Environmental Pollution 146(1), 139-146.

Lear, G., Harbottle, M.J., van der Gast, C.J., Jackman, S.A., Knowles, C.J., Sills, G., Thompson, I.P., 2004. The effect of electrokinetics on soil microbial communities. Soil Biology and Biochemistry 36(11), 1751-1760.

Li, H., Shi, W.-y., Shao, H.-b., Shao, M.-a., 2009. The remediation of the lead-polluted garden soil by natural zeolite. Journal of Hazardous Materials 169, 1106-1111.

Linkov, I., Varghese, A., Jamil, S., Saeger, T.P., Kiker, G., Bridges, T., 2004. Multi-criteria decision analysis: A framework for structuring remedial decisions at contaminated sites. In: Linkov, I., Ramadan, A. (Eds.), Comparative Risk Assessment and Environmental Decision Making. Kluwer, pp. 15-54.

Linkov, I., Satterstrom, F.K., Kiker, G., Batchelor, C., Bridges, T., Ferguson, E., 2006. From comparative risk assessment to multi-criteria decision analysis and adaptive management: Recent developments and applications. Environmental Risk Management - the State of the Art 32, 1072-1093.

MA, 2005. Millennium Ecosystem Assessment. Ecosystems and Human Well-being: Synthesis. Island Press, Washington, DC. 
Makino, T., Kamiya, T., Takano, H., Itou, T., Sekiya, N., Sasaki, K., Maejima, Y., Sugahara, K., 2007. Remediation of cadmium-contaminated paddy soils by washing with calcium chloride: Verification of on-site washing. Environmental Pollution 147(1), 112-119.

Mendoza, G.A., Martins, H., 2006. Multi-criteria decision analysis in natural resource management: A critical review of methods and new modelling paradigms. Forest Ecology and Management 230, 1-22.

Norrman, J., Volchko, Y., Rosén, L., Brinkhoff, P., Norin, M., Söderqvist, T., Kinell, G., Norberg, T., 2012. Development of a tool for evaluating the sustainability of remediation alternatives. Proceedings of the $16^{\text {th }}$ Nordic Geotechnical Meeting. Copenhagen, May 912, 2012. Vol. 2/2, dgf-Bulletin 27, 793-800.

Plaza, G., Nałęcz-Jawecki, G., Ulfig, K., Brigmon, R.L., 2005. The application of bioassays as indicators of petroleum-contaminated soil remediation Chemosphere 59, 289-296.

Postle, M., Fenn, T., Grosso, A., Steeds, J., 1999. Cost-benefit analysis for remediation of land contamination. R \& D Technical Report P316, Environment Agency, Bristol, UK.

Rodrigues, S.M., Pereira, M.E., Ferreira da Silva, E., Hursthouse, A.S., Duarte, A.C., 2009. A review of regulatory decisions for environmental protection: Part II-The case-study of contaminated land management in Portugal. Environment International 35(1), 214-225.

Rosén, L., Söderqvist, T., Back, P.E., Soutukorva, Å., Brodd, P., Grahn, L. 2008. Cost-benefit analysis (CBA) as a tool for prioritization of remedial actions at contaminated sites. Method development and examples. (In Swedish: Kostnads-nyttoanalys som verktyg för prioritering av efterbehandlingsinsatser. Metodutveckling och exempel på tillämpning.). Sustainable Remediation Programme, Report 5836. Swedish Environmental Protection Agency, Stockholm.

Rosén, L., Söderqvist, T., Back, P.E., Soutukorva, Å., Brodd, P., Grahn, L. 2009. Mulicriteria analysis (MCA) for sustainable remediation at contaminated sites. Method development and examples. (In Swedish: Multikriterieanalys (MKA) för hållbar efterbehandling av förorenade områden. Metodutveckling och exempel.). Programmet Hållbar Sanering. Sustainable Remediation Programme, Report 5891. Swedish Environmental Protection Agency, Stockholm.

Rönnbäck, P., Kautsky, N., Pihl, L., Troell, M., Söderqvist, T., Wennhage, H., 2007. Ecosystem Goods and Services from Swedish Coastal Habitats: Identification, Valuation, and Implications of Ecosystem Shifts. Ambio 36(7), 534-544.

SAB, 2009. Valuing the Protection of Ecological Systems and Services: A report of the EPA Science Advisory Board. Washington. EPA-SAB-09-012, May 2009. http://yosemite.epa.gov/sab/sabproduct.nsf/F3DB1F5C6EF90EE1852575C500589157/\$F ile/EPA-SAB-09-012-unsigned.pdf (accessed 05.06.11).

Sagoff, M., 2007. The Economy of the Earth: Philosophy, Law and the Environment. Second Edition. Cambridge University Press, Cambridge UK, 280 p.

Schädler, S., Morio, M., Bartke, S., Rohr-Zänker, R., Finkel, M., 2011. Designing sustainable and economically attractive browndfield revitalization options using an integrated assessment model. Journal of Environmental Management 92, 827-837.

Schindelbeck, R., van Es, H. M., Abawi, G. S., Wolfe, D.W., Whitlow, T.L., Gugino, B.K., Idowu, O.J., Moebius-Clune, B.N., 2008. Comprehensive assessment of soil quality for landscape and urban management. Landscape and Urban Planning 88, 73-80. 
Sparrevik, M., Barton, D.N., Bates M. E., Linkov, I., 2011. Use of stochastic multi-criteria decision analysis to support sustainable management of contaminated sediments. Environmental Science \& Technology 46, 1326-1334.

SuRF-UK, 2010. A framework for Assessing the Sustainability of Soil and Groundwater Remediation. CL:AIRE, London, 2010. 53 p.

http://www.claire.co.uk/index.php?option=com_phocadownload\&view=file \&id=61:initia

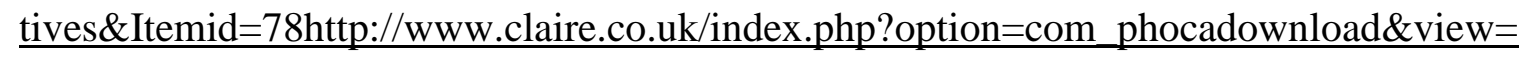
file\&id=61:initiatives\&Itemid=78 (accessed 05.06.11).

SuRF-UK, 2011. Annex 1: The SuRF-UK Indicator Set for Sustainable Remediation Assessment. CL:AIRE, London, November 2011. 18 p. http://www.claire.co.uk/index.php?option=com_resource\&controller=article\&article $=253$ \&category $\mathrm{id}=29 \&$ Itemid=61 (accessed 24.11.11).

Turner, K.R., van den Bergh, J.C.J.M., Söderqvist, T., Barendregt, A., van der Straaten, J., Maltby, E., van Ierland, E.C., 2000. Ecological-economic analysis of wetlands: scientific integration for management and policy. Ecological Economics 35, 7-2.

van den Bergh, J.C.J.M., 2010. Externality or sustainability economics? Ecological Economics 69(11), 2047-2052.

van Hees, P.A.W., Elgh-Dalgren, K., Engwall, M., von Kronhelm, T., 2008. Re-cycling of remediated soil in Sweden: An environmental advantage? Resources, Conservation and Recycling 52, 1349-1361.

Vegter, J., Lowe, J., Kasamas, H., 2003. Risk-based land management - a concept for the sustainable management of contaminated land. Land Contamination \& Reclamation 11 (1), 31-36. 
1 Fig. 1. Hourglass of sustainability: the linkages between the domains of sustainability and the ecosystem

2 functions and services.

13

Fig. 2. Incorporation of the soil function concept into a generic MCDA framework for sustainability appraisal in soil remediation projects. The grey arrows indicate the main flow of appraisal. The black arrows and the dotted box correspond to soil function evaluation within the appraisal.

\section{Table 1}

Key criteria for the ecological and the socio-cultural domains of sustainability (Rosén et al., 2009).

\section{Table 2}

A brief description of the studies examining the impact of remediation technologies on soil functionality.

\section{Table 3}

Impact of remediation technologies (see a description and references in Table 2) on soil quality indicators. 
Biotic and Abiotic Components \& Ecosystem Processes

\section{Utilization}

Functions

Economic Value of Ecosystem Goods and Services 
Step 1 Formulate Objectives and Select Methodology

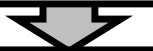

Step 2 Identify Remediation Alternatives

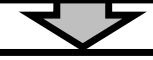

Step 3 Select Criteria

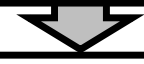

Step 4 Evaluate Remediation Alternatives against Criteria

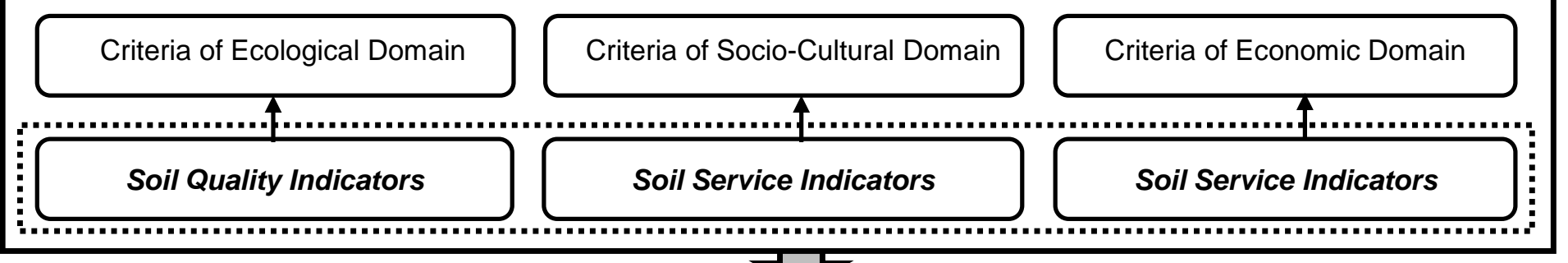

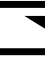

Step 5 Weight Criteria

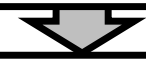

Step 6 Compare Remediation Alternatives and Perform Sensitivity Analysis 
Table 1

\begin{tabular}{ll}
\hline Ecological domain & Socio-cultural domain \\
\hline Land environment & Equity and acceptance \\
Groundwater & Health due to contamination at the site \\
Surface water & Health due to remediation \\
Air & Cultural environment \\
Sediments & Recreation \\
Consumption of natural resources & Land use on site \\
& Land use off site \\
\hline
\end{tabular}




\begin{tabular}{|c|c|c|c|c|c|c|c|c|}
\hline \multirow{2}{*}{ Remediation technology } & \multirow{2}{*}{$\begin{array}{l}\text { Type }{ }^{\text {a }} \\
\text { scale }\end{array}$} & \multirow{2}{*}{ Soil type } & \multirow{2}{*}{ Contaminant } & \multicolumn{2}{|c|}{ Concentration } & \multirow{2}{*}{$\begin{array}{l}\begin{array}{l}\text { Time } \\
\text { (days) }\end{array}\end{array}$} & \multirow{2}{*}{ Purpose/Comments } & \multirow{2}{*}{ Reference } \\
\hline & & & & $\mathrm{C}_{\text {before, }}\left(\mathrm{mg} \mathrm{kg}^{-1}\right)$ & Reduction, (\%) & & & \\
\hline Immobilization/ Zeolite & $\mathrm{L}$ & Sand & $\mathrm{Pb}$ & $125-2000$ & $30-47$ & 90 & $\begin{array}{l}\text { Evaluation of physical and chemical properties of garden soils and lead } \\
\text { uptake by colza after remediation by zeolite. }\end{array}$ & Li et al. (2009) \\
\hline Immobilization/ Biosolids & In-situ, F & $\begin{array}{l}\text { Alluvial tailings } \\
\text { deposits }\end{array}$ & $\begin{array}{l}\mathrm{Pb} \\
\mathrm{Zn} \\
\mathrm{Cd}\end{array}$ & $\begin{array}{l}3170 \\
1730 \\
15,9\end{array}$ & Not specified & 1095 & $\begin{array}{l}\text { Evaluation of the ecosystem functions after application of municipal } \\
\text { biosolids mixed with lime stone to metal-contaminated mine tailings in } \\
\text { Leadville, CO, USA. } 13 \text { species of plants, earthworms and } 5 \text { small } \\
\text { mammals were analyzed for toxicity. }\end{array}$ & Brown et al. (2005) \\
\hline Soil Washing & In-situ, F & Fluvaquent soil & $\mathrm{Cd}$ & 0,710 & $66-85$ & $\begin{array}{l}\text { Not } \\
\text { stated }\end{array}$ & $\begin{array}{l}\text { Evaluation of soil fertility after remediation of contaminated paddy } \\
\text { fields using soil washing tecnology. }\end{array}$ & Makino et al. (2007) \\
\hline Electrokinetics 1 & $\mathrm{~L}$ & $\begin{array}{l}\text { Evesham Series } \\
\text { heavy clay }\end{array}$ & \multicolumn{3}{|c|}{$\begin{array}{l}\text { polymers, amino acids, carbohydrates, amines, } \\
\text { carboxylic acids, phenols }\end{array}$} & 27 & $\begin{array}{l}\text { Evaluation of impact on soil microbial community caused by } \\
\text { electrokinetics (a laboratory soil cartridge microcosm). }\end{array}$ & Lear et al.(2004) \\
\hline Electrokinetics 2 & $\mathrm{~L}$ & $\begin{array}{l}\text { Evesham Series } \\
\text { heavy clay }\end{array}$ & PCB & 100 & 46 & 36 & $\begin{array}{l}\text { Evaluation of impact on soil microbial community caused by } \\
\text { electrokinetics (a laboratory soil cartridge microcosm). }\end{array}$ & Lear et al. (2007) \\
\hline Bio UN+T & \multirow[t]{4}{*}{$\mathrm{L}$} & \multirow[t]{4}{*}{ Ranker } & \multirow[t]{4}{*}{$\mathrm{PAH}$} & $260-310$ & $48-68$ & \multirow[t]{4}{*}{400} & $\begin{array}{l}\text { Evaluation of soil health after bioremediation, biopile, } \mathrm{UN}+\mathrm{T}- \\
\text { untreated, soil turned every } 2 \text { weeks. }\end{array}$ & \multirow[t]{4}{*}{ Dawson et al. (2007) } \\
\hline Bio NA+T & & & & $120-210$ & $32-33$ & & $\begin{array}{l}\text { Bioremediation, biopile, NA+T-100 C:15 N:1P ratio of nutrient } \\
\text { addition (as NH4NO3 and KH2PO4), soil turned every } 2 \text { weeks }\end{array}$ & \\
\hline Bio $\mathrm{SA}+\mathrm{T}$ & & & & $90-170$ & $24-27$ & & $\begin{array}{l}\text { Bioremediation, biopile, } \mathrm{SA}+\mathrm{T}-1 \%(\mathrm{v} / \mathrm{w}) \text { of surfactant addition } \\
\text { (sorbitan monooleate), soil turned every } 2 \text { weeks. }\end{array}$ & \\
\hline Bio MIX+T & & & & $90-190$ & $24-30$ & & $\begin{array}{l}\text { Bioremediation, biopile, MIX+T-equal mixtures of } \mathrm{UN}+\mathrm{T}, \mathrm{NA}+\mathrm{T} \text { and } \\
\mathrm{SA}+\mathrm{T} \text {, soil turned every } 2 \text { weeks. }\end{array}$ & \\
\hline Biopile A & \multirow{2}{*}{$\begin{array}{l}\text { Ex-situ } \\
\text { on site, } F\end{array}$} & \multirow[t]{2}{*}{ Acidic sludge } & \multirow[t]{2}{*}{$\mathrm{PAH}$} & \multirow[t]{2}{*}{6000} & 81 & 730 & \multirow{2}{*}{$\begin{array}{l}\text { Evaluation of soil health after remediation of manufactured gas plant, } \\
\text { Bioremediation, biopile, aerated (Biopile A) and non-aerated (Biopile } \\
\text { N). }\end{array}$} & \multirow[t]{2}{*}{ Plaza et al. (2005) } \\
\hline Biopile $\mathrm{N}$ & & & & & 30 & 240 & & \\
\hline \multirow[t]{2}{*}{ Phytoextraction 1} & \multirow[t]{2}{*}{$\mathrm{L}$} & \multirow[t]{2}{*}{ Clay loam } & $\mathrm{Zn}$ & 1000 & 37 & \multirow[t]{2}{*}{150} & \multirow{2}{*}{$\begin{array}{l}\text { Evaluation of soil health after phytoremediation by T. caerulescens } J \text {. } \\
\text { and } C \text {. Presl. }\end{array}$} & Epelde et al. (2008b) \\
\hline & & & $\begin{array}{l}\mathrm{Pb} \\
\mathrm{Cd}\end{array}$ & $\begin{array}{l}500 \\
100\end{array}$ & $\begin{array}{l}42 \\
32\end{array}$ & & & \\
\hline Phytoextraction+EDDS & $\mathrm{L}$ & Clay loam & $\mathrm{Pb}$ & 5000 & 55 & 120 & The EDDS (ethylene diamine Disuccinate)- and the EDTA (ethylene & Epelde et al. (2008a) \\
\hline & & & & 2500 & 43 & & diamine tetracetic acid)-mediated lead phytoextraction with $C y n a r a$ & \\
\hline Phytoextraction+ EDTA & & & & 5000 & 21 & & cardunculus. The impact caused by remediation on soil health & \\
\hline & & & & 2500 & 20 & & evaluated for soil contaminated with $\mathrm{Pb}$ concentration of $2500 \mathrm{mg} \mathrm{kg}^{-1}$ & \\
\hline Phytoextraction + SA & $\mathrm{L}$ & Sandy loam & $\mathrm{Zn}$ & 1000 & 13 & 30 & A pot experiment on phytoextraction by Lolium perenne with organic & Epelde et al. (2009) \\
\hline & & & $\mathrm{Pb}$ & 340 & 53 & & $(\mathrm{OA})$ and synthetic amendments (SA) for health evaluation of the & \\
\hline & & & $\mathrm{Cd}$ & 2.6 & 11 & & treated soil. & \\
\hline Phytorextraction $+\mathrm{OA}$ & & & $\mathrm{Zn}$ & 1000 & 32 & & & \\
\hline & & & $\mathrm{Pb}$ & 340 & 55 & & & \\
\hline & & & $\mathrm{Cd}$ & 2.6 & 37 & & & \\
\hline Phytoextraction 2 & $\mathrm{~L}$ & Clay loam & $\mathrm{Zn}$ & 1000 & 14 & 120 & Nine combination of metal pollution in soil have been studied to & Epelde et al. (2010) \\
\hline & & & $\mathrm{Cd}$ & 250 & 28 & & $\begin{array}{l}\text { evaluate the impact of the phytoextraction (by Thlaspi caerulescens) on } \\
\text { soil microbial communities. Functional gene distributions have been } \\
\text { evaluated by functional gene arrays (GeoChip) }\end{array}$ & \\
\hline
\end{tabular}

${ }^{\mathrm{a}}$ Type of remediation technique.

L: Lab experiment.

F: Field experiment. 


\section{Remediation Technologies}

\begin{tabular}{|c|c|c|c|c|c|c|c|c|c|c|c|c|c|c|c|c|}
\hline Soil quality indicators & 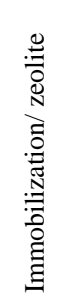 & 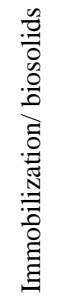 & 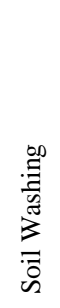 & 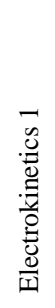 & 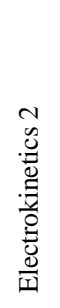 & 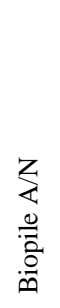 & 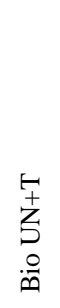 & 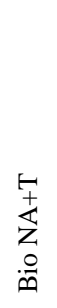 & \begin{tabular}{l}
+ \\
\pm \\
\multirow{2}{*}{} \\
.0 \\
0
\end{tabular} & 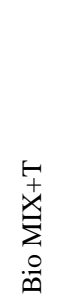 & 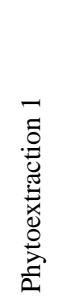 & 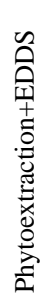 & 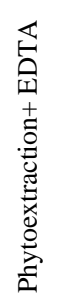 & 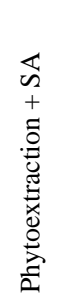 & 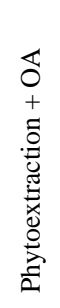 & 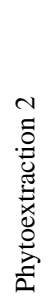 \\
\hline \multicolumn{17}{|l|}{ Physical } \\
\hline Particle size distribution & ++ & & & & & & & & & & & & & & & \\
\hline Soil structure & + & & & & & & & & & & & & & & & \\
\hline Soil texture & + & 0 & & & & & & & & & & & & & & \\
\hline Water holding capacity & & ++ & & ++ & & & - & - & ++ & ++ & & & & & & \\
\hline Organic matter & 0 & ++ & & & & & & & & & ++ & & & - & ++ & \\
\hline Temperature & & & & ++ & & & & & & & & & & & & \\
\hline \multicolumn{17}{|l|}{ Chemical } \\
\hline $\mathrm{pH}\left(\mathrm{H}_{2} \mathrm{O}\right)$ & ++ & ++ & - & - & - & & ++ & ++ & - & - & ++ & & & ++ & ++ & ++ \\
\hline $\mathrm{pH}\left(\mathrm{CaCl}_{2}\right)$ & & & & & & & ++ & - & - & - & & & & & & \\
\hline $\mathrm{pH}(\mathrm{KCl})$ & & & ++ & & & & & & & & & & & & & \\
\hline Total CEC & ++ & 0 & & & & & & & & & - & & & ++ & ++ & \\
\hline CEC(Kali, Magnesium) & & ++ & - & & & & & & & & & & & & & \\
\hline CEC (Calcium ) & & ++ & ++ & & & & & & & & & & & & & \\
\hline Total carbon & & ++ & - & & & & - & - & - & - & & & & & & \\
\hline Total nitrogen & & & - & & & & & & & & 0 & & & - & ++ & - \\
\hline Available Nitrogen & & ++ & - & & & & - & - & - & - & & & & & & \\
\hline Available Phosphorus & & ++ & ++ & & & & & & & & - & & & ++ & ++ & \\
\hline Available Kali & & & & & & & & & & & - & & & ++ & ++ & - \\
\hline Available Magnesium & & & & & & & & & & & ++ & & & & & \\
\hline Available Calcium & & & & & & & & & & & - & & & & & \\
\hline Electric conductivity & & & ++ & ++ & ++ & & & & & & - & & & - & - & \\
\hline \multicolumn{17}{|l|}{ Biological } \\
\hline Microbial biomass Carbon & & ++ & & ++ & + & & ++ & ++ & ++ & ++ & & & & ++ & ++ & ++ \\
\hline Micribial biomass Nitrogen & & ++ & & & & & & & & & & & & & & \\
\hline Respiration & & & & ++ & - & & - & - & - & - & & & & & & \\
\hline $\begin{array}{l}\text { Basal respiration/ Carbon } \\
\text { miniralization }\end{array}$ & & ++ & & & & & + & + & + & + & & - & - & & & - \\
\hline Substrate-induced respiration & & & & & & & & & & & & - & - & & & ++ \\
\hline Earthworm bioaccumulation & & - & & & & & & & & & & & & & & \\
\hline Earthworm survival & & ++ & & & & & ++ & ++ & ++ & ++ & & & & & & \\
\hline Small mammals survival & & ++ & & & & & & & & & & & & & & \\
\hline Dehydrogenase activity & & & & & & & ++ & ++ & ++ & ++ & & & & ++ & ++ & \\
\hline Enzyme activity & & & & & & & & & & & ++ & 0 & 0 & ++ & ++ & \\
\hline $\begin{array}{l}\text { Potentially mineralizable } \\
\text { Nitrogen }\end{array}$ & & ++ & & & & & + & + & + & + & & 0 & 0 & ++ & ++ & \\
\hline Species richness & & & & & & & & & & & & ++ & 0 & ++ & ++ & \\
\hline Shannon's diversity & & & & & & & & & & & & ++ & 0 & - & ++ & \\
\hline Seed germination & & & & & & ++ & ++ & ++ & ++ & ++ & & & & & & \\
\hline Root elongation & & & & & & ++ & & & & & & & & & & \\
\hline Dragonflies bioaccumulation & & & & & & - & & & & & & & & & & \\
\hline Ostracods bioaccumulation & & & & & & - & & & & & & & & & & \\
\hline
\end{tabular}

CEC: caution exchange capacity.

+: positive impact on the soil quality indicator is observed in the study without specifying a value of incremental increase in the parameter.

++ : an incremental increase in the parameter is specified in the study.

-: an incremental decrease in the parameter is specified in the study.

0 : no impact on the soil quality indicator is observed in the study. 